\title{
THE IMPACTS OF BRAND EXPERIENCES ON CUSTOMER SATISFACTION AND ELECTRONIC WORD OF MOUTH
}

\author{
Bader ALMOHAIMMEED D ${ }^{*}$ \\ Qassim University, Buraydah, Saudi Arabia
}

Received 21 January 2020; accepted 27 May 2020

\begin{abstract}
The problem addressed in this study is that the impact of the customer experience on the achievement of positive customer outcomes is still unknown in Arabic restaurants. Hence, the aim of this study is to explore the effect of brand experience, as measured through sensory, emotional, behavioural, and intellectual brand experience, on customer satisfaction and customer electronic word of mouth (eWOM) as well as the effect of customer satisfaction on eWOM. Data were collected using an electronic questionnaire consisting of 18 items distributed to a convenience sample of Facebook users. A total of 311 valid responses were collected. The participants were asked to evaluate their satisfaction and eWOM based on 6 items and their brand experience based on 12 items. Using IBM SPSS AMOS, the study revealed that three dimensions of brand experience (sensory, emotional, and behavioural) were significantly related to customer satisfaction and eWOM. Intellectual brand experience, according to the results of the current study, had no significant effect on customer satisfaction or eWOM. This conclusion is highlighted at the end of the paper along with its implications and recommendations. The contribution of this study stems from the fact that it alerts organizations to the factors influencing customer behaviour that ultimately lead to positive outcomes.
\end{abstract}

Keywords: sensory brand experience, emotional brand experience, behavioural brand experience, intellectual brand experience, brand experience, customer satisfaction, eWOM.

JEL Classification: M, M30, M31, M37, M39, C83.

\section{Introduction}

Organizations should reconsider their strategies, especially their marketing strategies, for a number of reasons. One reason is the growing number of brands and increasing competition among enterprises. In this regard, the researcher has monitored some complaints from restaurants, which have experienced a lack of frequent customers, and noted the failure of some restaurants and their inability to continue to operate. Hence, advice is needed that can be given to restaurants' managers to help them to recover and maintain their customer base.

Customer satisfaction and loyalty as key objectives for organizations have occupied a great deal of marketing literature. The factors that contribute to the achievement of these goals are extremely important, especially in the restaurant sector, and include direct interaction between the customers and the restaurant and the products and services that it offers. One of the most important topics mentioned by researchers is related to customer experience when interacting with a particular brand. Koetz
(2019) pointed out the need to improve customer experience and reward loyalty because they work to increase customer satisfaction and loyalty.

Researchers have shown that consumer experience occurs in certain situations, most importantly when searching for products, buying products, or receiving certain services. They have also defined customer experience as the impressions that are formed when interacting with those products or services (Brakus et al., 2009). Another study (Berry et al., 2002) added that clues sent by an organization to its customers affect them in different ways. The researchers also categorized the consumer or brand experience into several components to understand what this experience implies (Verhoef et al., 2009). The most common model used by researchers to identify customer brand experience is the model developed by Brakus et al. (2009), which consists of four types: sensory, affective, intellectual, and behavioural brand experience.

The study of customer experience is important for companies as they recognize that the factors influencing the purchasing behaviour of customers depend not only

*Corresponding author. E-mail: bmam@qu.edu.sa 
on the characteristics of the quality of products or services but also on other factors related to the physical and moral aspects of the customers. A number of studies have shown that customer experience has an impact on customer satisfaction and loyalty (Barnes et al., 2014; Liu \& Jang, 2009; Nysveen et al., 2013, Mohammed et al., 2017), customer engagement (Prentice et al., 2019), customer commitment (Iglesias et al., 2019), and electronic word of mouth (Jeong \& Jang, 2011). The problem that the current study addresses is that the impact of the customer experience on achieving positive customer outcomes is still widely unknown in Arabic restaurants; even when the impact is known, few are aware of it. Therefore, the importance of the current study stems from the fact that it alerts organizations to the factors influencing customer behaviour that ultimately lead to positive outcomes.

\section{Literature review and hypothesis development}

\subsection{Definition of customer experience}

Customer experience and experience are used interchangeably in the current study. Customer experience has been defined from numerous perspectives. Verhoef et al. (2009) indicated that customer experience is a multidimensional construct built on a customer's physical, social, cognitive, and affective states, which originate from his or her responses to the firm. Berry et al. (2002) explained customer experience with reference to clues sent from a firm to its customers. Brakus et al. (2009) identified four cases in which consumer experience of goods and services occurs: searching for products, shopping for products, receiving services, and consuming products or services. Consequently, customer experience was defined for the purpose of the current study as the occurrence of an impression due to a product- or service-related event. That is, a customer who encounters a product or service forms a cognitive, emotional, social, or physical impression of the product or the service itself, the place where this product or service is delivered, and the personnel who are responsible for providing such a product or service.

\subsection{Dimensions of customer experience}

Understanding the dimensions of customer experience requires a prerequisite step in which one can perceive how scholars have operationalized this construct as well as which drivers of customer experience have been reported by authors. A considerable amount of marketing literature has been dedicated to the drivers of customer experience. For Berry et al. (2002), the clues that a firm sends to its customers are a key driver of customer experience. The authors divided these clues into two key categories: thing-related clues, which represent product or service functionality, and human-originated clues, which constitute workers' emotional responses. In fact, these insights are related to customer experience management, which is a pivotal skill that firms should develop. According to
Verhoef et al. (2009), customer experience is generated by controllable and uncontrollable elements. These elements were portrayed by the authors in their proposed model of customer experience creation, which reported drivers of customer experience, that is, the social environment, service interface, retail atmosphere, price, retail brand, customer past experience, assortment, and customer experience in alternative channels.

Regarding the conceptualization of customer experience, Brakus et al. (2009) divided customer experience into a number of key categories, which are product experience, shopping and service experience, and consuming experience. The authors identified two types of product experience: direct and indirect experience. Direct product experience occurs in the case of physical interaction between the customer and the product, while indirect product experience is embedded in virtual or advertised products. A firm's physical environment, employees, and practices are indicators of shopping and service experience. Finally, feeling pleasure during or after consumption of the product is the core of consuming experience.

Schmitt (1999, cited in Hosany \& Witham, 2010) conceptualized this construct in terms of five types of experience: physical experience, sensory experience, cognitive experience, social identity experience, and affective experience. Hosany and Witham (2010) explored the dimensions of tourists' experience and found that it consists of four major dimensions: education, entertainment, escapism, and aesthetics. In their scale developed to measure brand experience, Brakus et al. (2009) validated a model consisting of four dimensions: sensory, affective, intellectual, and behavioural brand experience. Similarly, Zhang (2019) explored the effect of brand experience on brand loyalty, measuring brand experience through sensory, emotional, thinking, action, and related brand experiences.

In the dining industry, dimensions of customer experience can be understood through restaurant attributes such as food quality, service quality, restaurant atmosphere, and price fairness (Liu \& Jang, 2009). In a study on the relationship between customer dining experience in lunch and supper restaurants, Andersson and Mossberg (2004) found that lunch customers are more focused on psychological needs while supper customers are more socially oriented. To assess customer experience, they asked customers to evaluate their willingness to pay for particular aspects of their restaurant experience, such as dining service, food quality, food cuisine, restaurant interior design, and other customers. Other dimensions of customer experience identified by authors include restaurant environmental factors and customer interactions with restaurant employees and other customers (Wu \& Liang, 2009). Table 1 summarizes the dimensions of brand experience found in the literature.

For the current study, four dimensions of brand experience were used following Brakus et al. (2009) - sensory, emotional, intellectual, and behavioural experience - due 
to the fact that these types are the most common dimensions used by researchers (Zhang, 2019). Sensory experience refers to the extent to which the experience affects the five senses of the customer (Brakus et al., 2009; Iglesias et al., 2019). Emotional experience describes customers' affective engagement with a brand that results in a positive feeling towards the brand (Ebrahim et al., 2016). Thought, curiosity, and problem solving are key components of intellectual brand experience; furthermore, physical actions are the core of behavioural experience (Barnes et al., 2014).

Table 1. Brand experience in the literature

\begin{tabular}{|l|l|}
\hline \multicolumn{1}{|c|}{ Dimensions } & \multicolumn{1}{|c|}{ Authors } \\
\hline $\begin{array}{l}\text { Physical experience, sensory experience, } \\
\text { cognitive experience, social identity } \\
\text { experience and affective experience }\end{array}$ & $\begin{array}{l}\text { Schmitt (1999, } \\
\text { cited in Hosany \& } \\
\text { Witham, 2010) }\end{array}$ \\
\hline $\begin{array}{l}\text { Dining service, food quality, food cuisine, } \\
\text { restaurant interior design and other } \\
\text { customers. }\end{array}$ & $\begin{array}{l}\text { Andersson and } \\
\text { Mossberg (2004) }\end{array}$ \\
\hline $\begin{array}{l}\text { Social environment, service interface, } \\
\text { retail atmosphere, price, retail brand, } \\
\text { customer past experience, assortment, } \\
\text { and customer experiences in alternative } \\
\text { channels. }\end{array}$ & $\begin{array}{l}\text { Verhoef et al. } \\
(2009)\end{array}$ \\
\hline $\begin{array}{l}\text { Sensory brand experience, affective brand } \\
\text { experience, intellectual brand experience, } \\
\text { behavioral brand experience brand } \\
\text { experience. }\end{array}$ & $\begin{array}{l}\text { Brakus et al. } \\
(2009)\end{array}$ \\
\hline $\begin{array}{l}\text { Restaurant attributes like food quality, } \\
\text { service quality, restaurant atmosphere, and } \\
\text { price fairness. }\end{array}$ & $\begin{array}{l}\text { Liu and Jang } \\
(2009)\end{array}$ \\
\hline $\begin{array}{l}\text { Restaurant environmental factors and } \\
\text { customer interactions. }\end{array}$ & $\begin{array}{l}\text { Wu and Liang } \\
(2009)\end{array}$ \\
\hline $\begin{array}{l}\text { Sensory brand experience, affective brand } \\
\text { experience, intellectual brand experience, } \\
\text { behavioral brand experience, and } \\
\text { relational brand experience. }\end{array}$ & $\begin{array}{l}\text { Nysveen et al. } \\
(2013)\end{array}$ \\
\hline $\begin{array}{l}\text { Sensory experience, affective experience, } \\
\text { intellectual experience, and behavioral } \\
\text { experience. }\end{array}$ & $\begin{array}{l}\text { Barnes et al. } \\
(2014)\end{array}$ \\
\hline $\begin{array}{l}\text { Sensory brand experience, emotional } \\
\text { brand experience, thinking brand } \\
\text { experience, action brand experience, and } \\
\text { related brand experience. }\end{array}$ & Zhang (2019) \\
\hline Shand
\end{tabular}

\subsection{Effects of customer experience on customer outcomes}

The literature on customer experience can be divided into two types: research on the relative importance of experience aspects (e.g., Andersson \& Mossberg, 2004) and research on the effects of customer experience on customer outcomes, such as customer satisfaction and behavioural intentions (e.g., Liu \& Jang, 2009). Investigating customers' meal experience in luxury-hotel restaurants, $\mathrm{Wu}$ and Liang (2009) found that the restaurant environment and customers' interactions with restaurant employees and other customers had a significant effect, either directly or indirectly, on customer satisfaction. Brakus et al. (2009) conducted a study to develop a scale to measure brand experience and to investigate the impact of brand experience on customer satisfaction as well as loyalty and found that brand experience had a positive effect on customer satisfaction and loyalty either directly or indirectly through brand personality. Nysveen et al. (2013) asserted that brand experience has a significant influence on brand personality, brand satisfaction, and brand loyalty.

Other related studies on brand experience have pointed out positive effects of this construct on customer outcomes. Prentice et al. (2019) carried out a study on the airline industry to examine the effect of customer-based factors, specifically brand experience and brand love, and firmbased factors on customer engagement and revealed that customer-based factors had a significant influence on customer engagement. Particularly, brand experience had direct and indirect influences on customer engagement. Das et al. (2019) examined the impact of brand experience on brand commitment in the presence of brand passion as a mediating variable and brand ethical perception as a moderating variable. Their results indicated that brand experience was positively related to brand commitment through full mediation of brand passion. According to the results of Shanti et al. (2019), brand experience had significant effects on both brand satisfaction and brand love but not on brand loyalty. Generally stated, brand experience exerts a significant effect on customer satisfaction, loyalty, engagement, and commitment.

Specifically, Iglesias et al. (2019) investigated the influence of sensory brand experience on brand equity as mediated by customer satisfaction and customer affective commitment and the influence of sensory brand experience on customer satisfaction and customer affective commitment as moderated by employee empathy. In terms of the effects of sensory brand experience, it was revealed that this variable had an indirect influence on brand equity when the relationship between these two variables was mediated by customer satisfaction. Employee empathy was found to play a negative moderating role between sensory brand experience and customer satisfaction. Exploring the relationships between five dimensions of brand experience - sensory emotional thinking action and related brand experience, Zhang (2019) underlined a positive impact of these five experiences on brand loyalty. In their examination of the effects of brand experience in the tourism context as measured through sensory, affective, behavioural, and intellectual experience, Barnes et al. (2014) indicated that visitor satisfaction, intention to recommend, and intention to revisit can be predicted by sensory destination experience.

On the other hand, brand experience has been found to play a significant role in the context of some related variables, like consumers' word of mouth (WOM) regarding the brand itself. Klein et al. (2016) found that brand experience mediated the relationship between brand store characteristics and WOM. Karjaluoto et al. (2016) examined the moderating role of experience and price in the relationship 
between brand love and both offline and online word of mouth. The results showed that experience and price were positively related to offline WOM but not to online WOM (eWOM). Furthermore, brand experience emerged as a construct with a significant effect on eWOM (Chen et al., 2014). In Kim et al. (2015) study on brand experience, customer satisfaction, and loyalty in the shopping mall context, it was found that brand experience had a significant effect on customer satisfaction, customer loyalty, and brand personality. Additionally, satisfaction had a significant effect on customer loyalty. Examining the relationship between restaurant experience and eWOM, the results obtained by Jeong and Jang (2011) indicated that a restaurant's food quality, staff satisfactory experience, and good-quality atmosphere were three indispensable predictors of customers' eWOM.

Accordingly, the following hypotheses were developed:

$\mathrm{H1}$ : Brand sensory experience has a significant and positive effect on customer satisfaction.

$\mathrm{H} 2$ : Brand emotional experience has a significant and positive effect on customer satisfaction.

H3: Brand behavioural experience has a significant and positive effect on customer satisfaction.

H4: Brand intellectual experience has a significant and positive effect on customer satisfaction.

H5: Brand sensory experience has a significant and positive effect on eWOM.

H6: Brand emotional experience has a significant and positive effect on eWOM.

H7: Brand behavioural experience has a significant and positive effect on eWOM.

$\mathrm{H} 8$ : Brand intellectual experience has a significant and positive effect on eWOM.

H9: Customer satisfaction has a significant and positive effect on eWOM.

\section{Methodology}

\subsection{Sampling}

A convenience sample of brand restaurant fans on Facebook was used to collect data for the purpose of this study. A total of 311 individuals responded to the request to complete the questionnaire. Data were collected during three days at the beginning of October 2019. Collecting data from Facebook users through the online survey method is a common approach for researchers (Chen et al., 2014).

\subsection{Model}

Figure 1 shows the conceptual model of the present study, in which five independent latent variables, namely sensory, emotional, behavioural, intellectual, and satisfaction, were hypothesized to exert significant effects on a dependent latent construct, specifically customers' eWOM, via nine hypotheses (H1-H9). It should be noted here that the objectives of the current study did not include testing the mediating impact of customer satisfaction.

\subsection{Instrument}

Brand experience was measured using the Brand Experience Scale developed by Brakus et al. (2009), which is a reliable and valid scale encompassing twelve items as openended questions delivered to assess four types of brand experience: sensory experience, affective experience, intellectual experience, and behavioural experience. The items of sensory brand experience in the Brand Experience Scale were used by Iglesias et al. (2019) to measure sensory brand experience. Customer satisfaction was assessed using three items: dining experience, good mood (Al-Tit, 2015), and visualization of food appearance as evaluated through components, colour, shape, layout, and texture (Putra et al., 2018). EWOM was measured by adapting three items used by Chen et al. (2014). The items of the instrument were measured using a five-point Likert scale ranging from one point (strongly disagree) to five points (strongly agree).

\section{Results and discussion}

\subsection{Exploratory factor analysis}

Exploratory factor analysis (EFA) was performed to achieve two goals: (1) to explore the factors' dimensionality

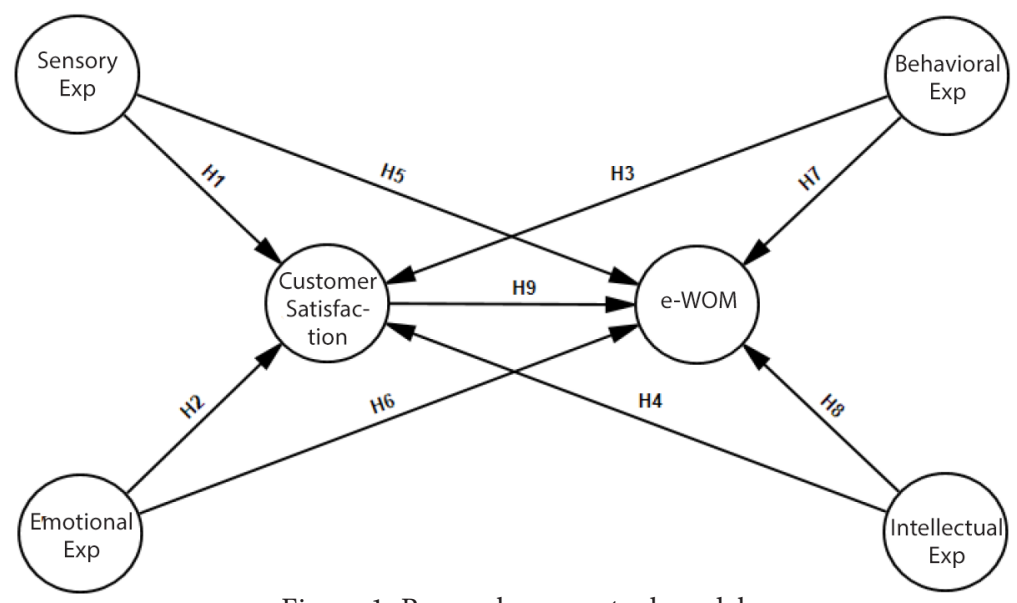

Figure 1. Research conceptual model 
and (2) to investigate validity and reliability. The results shown in Table 2 signify that three indicators were loaded on sensory brand experience (XB1, XB2, and XB3) with standardized factor loadings ranging between 0.69 and 0.74. Similarly, three indicators (XB4, XB5, and XB6) were loaded on emotional brand experience. Their standardized factor loadings were $0.78,0.75$, and 0.71 , respectively. Behavioural brand experience, according to the results, was related to three indicators (XB7, XB8, and XB9), with standardized factor loadings ranging between 0.68 and 0.83 . Moreover, three indicators were loaded on intellectual brand experience (XB10, XB11, and XB12), with standardized factor loadings ranging between 0.88 and 0.94 .

Table 2. Results of EFA

\begin{tabular}{|c|c|c|c|c|c|}
\hline $\begin{array}{c}\text { Factors } \\
\text { and } \\
\text { indicators }\end{array}$ & Items & SFL & AVE & CR & $\alpha$ \\
\hline \multirow{3}{*}{$\begin{array}{l}\text { Sensory } \\
\text { brand } \\
\text { experience }\end{array}$} & BX1 & 0.74 & \multirow{3}{*}{0.514} & \multirow{3}{*}{0.760} & \multirow{3}{*}{0.751} \\
\hline & $\mathrm{BX} 2$ & 0.72 & & & \\
\hline & $\mathrm{BX} 3$ & 0.69 & & & \\
\hline \multirow{3}{*}{$\begin{array}{l}\text { Emotional } \\
\text { brand } \\
\text { experience }\end{array}$} & $\mathrm{BX} 4$ & 0.78 & \multirow{3}{*}{0.558} & \multirow{3}{*}{0.791} & \multirow{3}{*}{0.782} \\
\hline & BX5 & 0.75 & & & \\
\hline & BX6 & 0.71 & & & \\
\hline \multirow{3}{*}{$\begin{array}{l}\text { Behavioral } \\
\text { brand } \\
\text { experience }\end{array}$} & BX7 & 0.83 & \multirow{3}{*}{0.576} & \multirow{3}{*}{0.802} & \multirow{3}{*}{0.793} \\
\hline & BX8 & 0.76 & & & \\
\hline & BX9 & 0.68 & & & \\
\hline \multirow{3}{*}{$\begin{array}{l}\text { Intellectual } \\
\text { brand } \\
\text { experience }\end{array}$} & BX10 & 0.76 & \multirow{3}{*}{0.563} & \multirow{3}{*}{0.794} & \multirow{3}{*}{0.782} \\
\hline & BX11 & 0.74 & & & \\
\hline & BX12 & 0.75 & & & \\
\hline \multirow{3}{*}{$\begin{array}{l}\text { Customer } \\
\text { Satisfaction }\end{array}$} & CS1 & 0.84 & \multirow{3}{*}{0.657} & \multirow{3}{*}{0.851} & \multirow{3}{*}{0.832} \\
\hline & CS2 & 0.81 & & & \\
\hline & CS3 & 0.78 & & & \\
\hline \multirow{3}{*}{ e-WOM } & eWOM1 & 0.94 & \multirow{3}{*}{0.835} & \multirow{3}{*}{0.938} & \multirow{3}{*}{0.921} \\
\hline & eWOM2 & 0.92 & & & \\
\hline & eWOM3 & 0.88 & & & \\
\hline
\end{tabular}

On the other hand, all the values of the average variance extracted (AVE) were greater than 0.50 (Al-Ayed, 2019; Almohaimmeed, 2017; Al-Tit, 2016), which indicated that validity was assured. Reliability was also supported; that is, the composite reliability (CR) values and Cronbach's alpha coefficients $(\alpha)$ were greater than 0.7 (AlTit et al., 2019; Sweis et al., 2013).

\subsection{Model fit}

Five model fit indices were used to explore the extent to which the current model fit the data as shown in Figure 2. Table 3 asserted that the current model was acceptable (Shi et al., 2019). According to Hooper et al. (2008), the chisquared test, GFI (goodness-of-fit index), AGFI (adjusted goodness-of-fit index), and RMSEA (root mean square error of approximation) are three indices of absolute fit and the CFI (comparative fit index) is one of the incremental fit indices. The authors explained that the absolute fit indices represent a measure of the goodness of model fit in comparison with no model while the incremental fit indices depend on a baseline model.

Table 3. Results of model fit

\begin{tabular}{|l|c|c|}
\hline \multicolumn{1}{|c|}{ Index } & Value & Criterion \\
\hline Chi-square ratio (CMIN/DF) & 2.27 & $>3.00$ \\
\hline Goodness of Fit Index (GFI) & 0.91 & $>0.90$ \\
\hline $\begin{array}{l}\text { Adjusted for Goodness of Fit Index } \\
\text { (AGFI) }\end{array}$ & 0.88 & $>0.90$ \\
\hline Comparative Fit Index (CFI) & 0.942 & $>0.90$ \\
\hline $\begin{array}{l}\text { Root Mean Square Error of } \\
\text { Approximation RMSEA) }\end{array}$ & 0.051 & $<0.08$ \\
\hline
\end{tabular}

\subsection{Structural model}

Figure 3 displays the structural model used in the current study to test its hypotheses. A detailed presentation of the regression coefficients with their associated t-value and significance values can be seen in Table 4 .

In light of the results in Table 4, all the dimensions of brand experience, that is, sensory $(B=0.16, t=3.74$, $\mathrm{p}<0.05)$, emotional $(\beta=0.48, \mathrm{t}=17.357, \mathrm{p}<0.05)$ and behavioural experiences $(B=0.35, \mathrm{t}=13.614, \mathrm{p}<0.05)$, except intellectual brand experience $(\beta=0.05, \mathrm{t}=0.8, \mathrm{p}>$ 0.05 ), were found to be significant predictors of customer satisfaction.

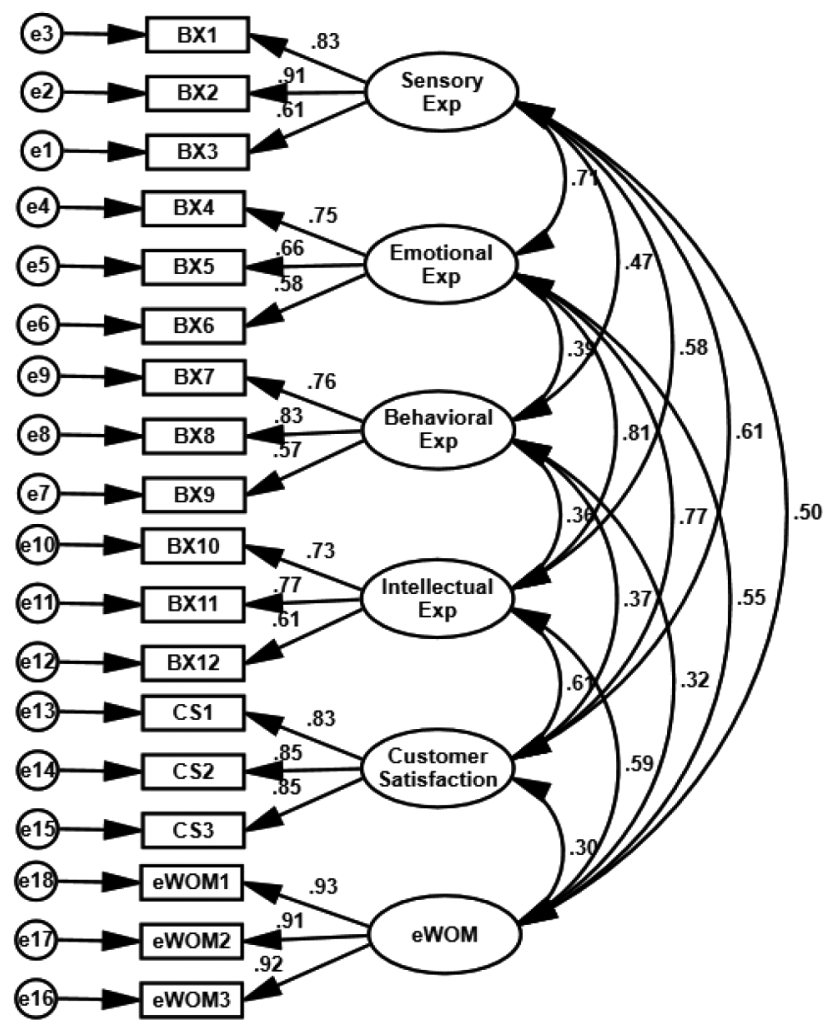

Figure 2. Research measurement model 
What is more, sensory brand experience had a significant effect on eWOM $(\beta=0.30, \mathrm{t}=11.22, \mathrm{p}<0.05)$, emotional brand experience exerted a significant effect on

Table 4. Results of the hypothesis testing

\begin{tabular}{|l|l|l|c|c|c|}
\hline \multicolumn{2}{|c|}{ Path } & $\beta$ & $\mathrm{t}$-value & $\mathrm{P}$ value \\
\hline $\begin{array}{l}\text { Sensory brand } \\
\text { experience }\end{array}$ & $\rightarrow$ & $\begin{array}{l}\text { Customer } \\
\text { satisfaction }\end{array}$ & 0.16 & 3.742 & 0.0000 \\
\hline $\begin{array}{l}\text { Emotional } \\
\text { brand } \\
\text { experience }\end{array}$ & $\rightarrow$ & $\begin{array}{l}\text { Customer } \\
\text { satisfaction }\end{array}$ & 0.48 & 17.357 & 0.001 \\
\hline $\begin{array}{l}\text { Behavioral } \\
\text { brand } \\
\text { experience }\end{array}$ & $\rightarrow$ & $\begin{array}{l}\text { Customer } \\
\text { satisfaction }\end{array}$ & 0.35 & 13.614 & 0.002 \\
\hline $\begin{array}{l}\text { Intellectual } \\
\text { brand } \\
\text { experience }\end{array}$ & $\rightarrow$ & $\begin{array}{l}\text { Customer } \\
\text { satisfaction }\end{array}$ & 0.05 & 0.759 & 0.342 \\
\hline $\begin{array}{l}\text { Sensory brand } \\
\text { experience }\end{array}$ & $\rightarrow$ & $\begin{array}{l}\text { Customer } \\
\text { eWOM }\end{array}$ & 0.30 & 11.224 & 0.001 \\
\hline $\begin{array}{l}\text { Emotional } \\
\text { brand } \\
\text { experience }\end{array}$ & $\rightarrow$ & $\begin{array}{l}\text { Customer } \\
\text { eWOM }\end{array}$ & 0.17 & 3.882 & 0.000 \\
\hline $\begin{array}{l}\text { Behavioral } \\
\text { brand } \\
\text { experience }\end{array}$ & $\rightarrow$ & $\begin{array}{l}\text { Customer } \\
\text { eWOM }\end{array}$ & 0.12 & 3.427 & 0.000 \\
\hline $\begin{array}{l}\text { Intellectual } \\
\text { brand } \\
\text { experience }\end{array}$ & $\rightarrow \begin{array}{l}\text { Customer } \\
\text { eWOM }\end{array}$ & 0.08 & 1.132 & 0.415 \\
\hline $\begin{array}{l}\text { Customer } \\
\text { satisfaction }\end{array}$ & $\rightarrow$ & $\begin{array}{l}\text { Customer } \\
\text { eWOM }\end{array}$ & 0.56 & 21.367 & 0.002 \\
\hline
\end{tabular}

eWOM $(\beta=0.17, \mathrm{t}=3.88, \mathrm{p}<0.05)$, and behavioural brand experience significantly predicted eWOM $(B=0.12$, $\mathrm{t}=3.43, \mathrm{p}<0.05)$, while intellectual brand experience had no significant effect on eWOM $(B=0.08, t=1.13, p>$ $0.05)$. Customer satisfaction had a significant effect on eWOM $(B=0.56, t=21.37, p<0.05)$. Based on these results, hypotheses $\mathrm{H1}, \mathrm{H} 2, \mathrm{H} 3, \mathrm{H} 5, \mathrm{H} 6$, and $\mathrm{H} 7$ were supported by the current data. That is, sensory, emotional, and behavioural brand experiences affected customer satisfaction while intellectual brand experience ( $\mathrm{H} 4$ and $\mathrm{H} 8$ ) had no such effect. Additionally, H9 was supported.

The results of the current study are not the first of their kind, as previous studies have obtained similar results with the exception of the result concerning intellectual experience and its impact on customer satisfaction. Sensory experience was measured in the present study by reference to the strong impression that comes as a result of the characteristics of the restaurant and food, and their attractive impact on the senses of consumers has been shown in previous studies as having an impact on customer satisfaction. The emotional experience, measured in the study using positive emotions formed due to the restaurant and food experience, has an impact on customer satisfaction. In contrast, the behavioural experience reflects the actions of the customers or how they are encouraged to act by the brand. Finally, the intellectual experience was measured by thinking or problem solving during the interaction with the brand. Examples of studies that have agreed with the current findings include Iglesias et al. (2019), Shanti et al.

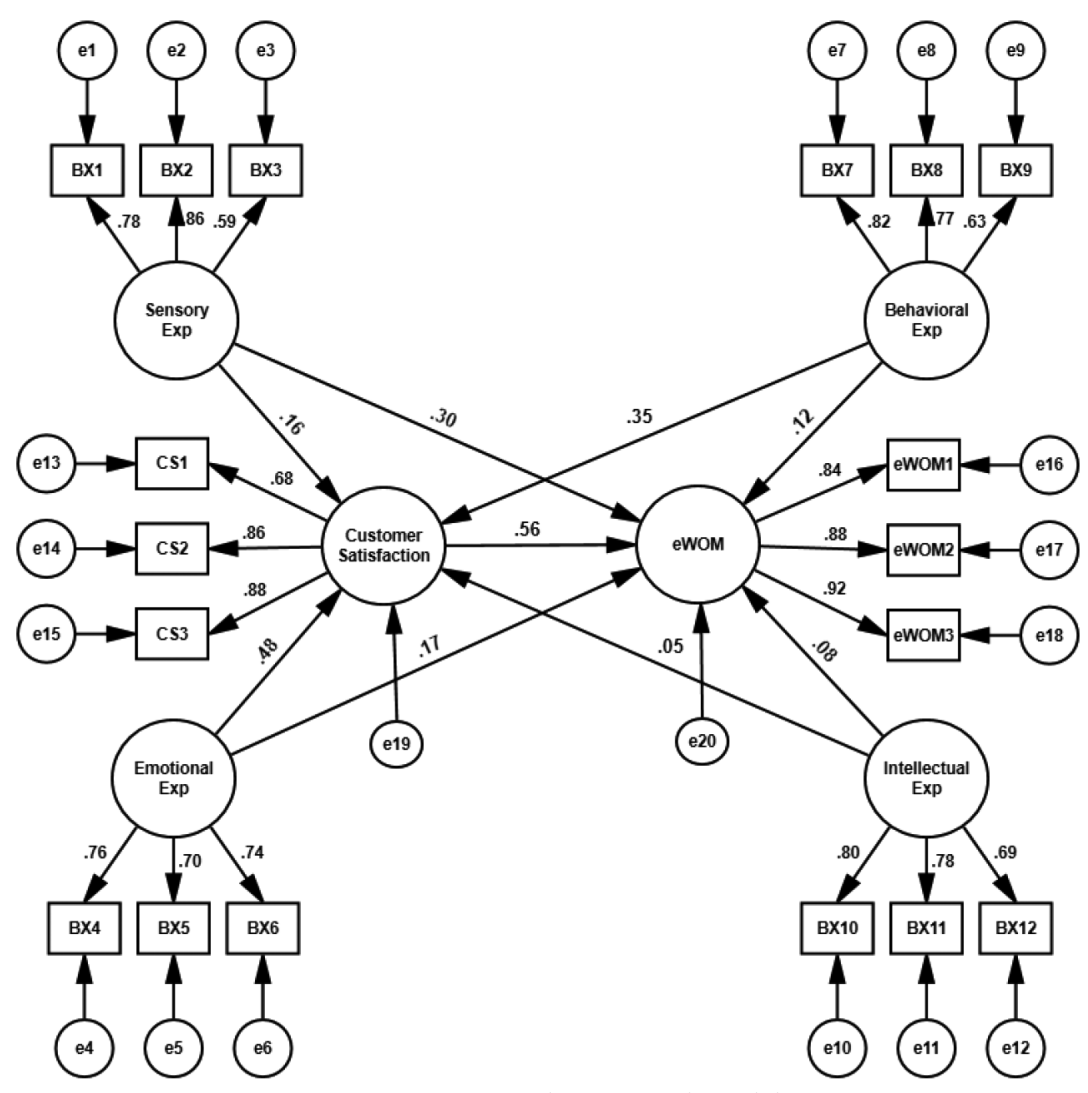

Figure 3. Research structural model 
(2019), and Zhang (2019). In terms of the effect of brand experience on eWOM, this study's results are similar to those shown by Jeong and Jang's (2011) study. However, to the best of the researcher's knowledge, no studies have been conducted on the non-significant effect of intellectual brand experience on customer satisfaction and eWOM.

\section{Conclusions and recommendations}

The aim of this study was to explore the effects of four dimensions of brand experience, that is, sensory, emotional, behavioural, and intellectual brand experience, on customer satisfaction and customer eWOM and to investigate the effect of customer satisfaction on customer eWOM. The results showed that sensory, emotional, and behavioural brand experience are three crucial predictors of customer satisfaction and eWOM. Intellectual brand experience was found to exert no significant impact on customer satisfaction and eWOM.

Understanding different types of consumer experience is important in several ways. First, it is necessary to understand the needs of consumers as consumers who visit a restaurant are not only affected by the quality of the food but also have a sensory, emotional, and behavioural experience. Second, it is possible to understand the experience that is formed by consumers when interacting with the restaurant to determine the most suitable marketing strategy to meet customer needs and produce satisfaction. Therefore, restaurants can encourage customers to spread positive publicity about them through social media, especially in light of the large spread of these media. Third, restaurants can make adjustments to the way in which they manage their business and provide food and services. Fourth, consumers' positive word-of-mouth assurance is closely linked to customer satisfaction. Thus, customer satisfaction must be achieved first.

Surprisingly, the results of the study showed that customers' behavioural experience has an impact on customer satisfaction and positive word of mouth. The reason for this may be that the nature of the restaurants that the respondents mentioned is open and includes open spaces that encourage physical actions, such as restaurants in resorts, which offer possibilities of walking, sitting by the pool, watching the landscape, swimming in the pool, and other activities.

In the light of the foregoing conclusions, the study recommends that restaurant owners and managers should consider the results of the current study by focusing on the sensory experience of the customers, which includes all the human senses, as well as on their emotional experience, as this increases the relationship between the customers and the restaurant, especially as those emotions become memories for them. One of the most important recommendations of the study here is to try to achieve a positive customer experience in all aspects, whether in terms of food or in terms of other aspects of the restaurant. There are some recommendations for researchers, such as conducting future studies to detect the impact of customers' intellectual experience, as the results of the current study indicate that it does not affect customer satisfaction or word of mouth. Researchers are also required to identify the impact of the above-mentioned experiments using different institutions or brands.

Customer demographic characteristics have gained considerable attention in marketing research. Wägar and Lindqvist (2010) examined the perceptions of older and younger customer contact persons, and Foster and Resnick (2013) explored the influence of some characteristics of service workers, like gender and age, on customer service perceptions. Rahman (2012) tested the mediating role of such characteristics in the relationship between customer perception and behaviour. Parahoo et al. (2014) investigated the influence of passengers' age on their usage of metro and tram services. Zniva and Weitzl (2016) reviewed the literature on older customer behaviour. Kylkilahti and Autio (2018) focused on the tactics of younger customers in daily service interactions. Afthinos et al. (2005) identified customer service expectations due to particular patterns, like gender and age. Therefore, researchers are called to consider customer demographic characteristics in their marketing research, particularly regarding brand experience, satisfaction, and loyalty. The practical implications of this study determine when consumers search for brand experiences when they are shopping and consuming brands.

\section{Limitations}

The current study has several limitations. First, the sample of the study consisted of Facebook users, and they were asked what they thought about their experiences when interacting with certain brands or places. Second, the focus of the study questionnaire was on restaurants. It is possible that the respondents expressed their opinion having not necessarily lived any of these experiences, as the questionnaires were distributed over the Internet and not in the restaurants themselves. Finally, the responses were determined in the light of the items adopted from Brakus et al. (2009) to measure brand experience in addition to other items taken from Al-Tit (2015), Chen et al. (2014), and Putra et al. (2018) to assess customer satisfaction and eWOM.

\section{References}

Afthinos, Y., Theodorakis, N. D., \& Nassis, P. (2005). Customers' expectations of service in Greek fitness centers: Gender, age, type of sport center, and motivation differences. Managing Service Quality: An International Journal, 15(3), 245-258. https://doi.org/10.1108/09604520510597809

Al-Ayed, S. I. (2019). The impact of strategic human resource management on organizational resilience: an empirical study on hospitals. Verslas: teorija ir praktika, 20(1), 179-186. https://doi.org/10.3846/btp.2019.17

Almohaimmeed, B. M. (2017). Restaurant quality and customer satisfaction. International Review of Management and Marketing, 7(3), 42-49. 
Al-Tit, A., Omri, A., \& Euchi, J. (2019). Critical success factors of small and medium-sized enterprises in Saudi Arabia: insights from sustainability perspective. Administrative Sciences, 9(2), 32. https://doi.org/10.3390/admsci9020032

Al-Tit, A. (2015). The effect of service and food quality on customer satisfaction and hence customer retention. Asian Social Science, 11(23), 129. https://doi.org/10.5539/ass.v11n23p129

Al-Tit, A. (2016). Management information systems in public institutions in Jordan: an eye on implementation success factors and their relationship with organizational performance. International Journal of Advanced Computer Science and Applications, 7(7), 457-463. https://doi.org/10.14569/IJACSA.2016.070763

Andersson, T. D., \& Mossberg, L. (2004). The dining experience: do restaurants satisfy customer needs? Food Service Technology, 4(4), 171-177. https://doi.org/10.1111/j.1471-5740.2004.00105.x

Barnes, S. J., Mattsson, J., \& Sørensen, F. (2014). Destination brand experience and visitor behavior: Testing a scale in the tourism context. Annals of Tourism Research, 48, 121-139. https://doi.org/10.1016/j.annals.2014.06.002

Berry, L. L., Carbone, L. P., \& Haeckel, S. H. (2002). Managing the total customer experience. MIT Sloan Management Review, 43(3), 85-89.

Brakus, J. J., Schmitt, B. H., \& Zarantonello, L. (2009). Brand experience: what is it? How is it measured? Does it affect loyalty? Journal of Marketing, 73(3), 52-68. https://doi.org/10.1509/jmkg.73.3.52

Chen, H., Papazafeiropoulou, A., Chen, T. K., Duan, Y., \& Liu, H. W. (2014). Exploring the commercial value of social networks: Enhancing consumers' brand experience through Facebook pages. Journal of Enterprise Information Management, 27(5), 576-598. https://doi.org/10.1108/JEIM-05-2013-0019

Das, G., Agarwal, J., Malhotra, N. K., \& Varshneya, G. (2019). Does brand experience translate into brand commitment?: A mediated-moderation model of brand passion and perceived brand ethicality. Journal of Business Research, 95, 479-490. https://doi.org/10.1016/j.jbusres.2018.05.026

Ebrahim, R., Ghoneim, A., Irani, Z., \& Fan, Y. (2016). A brand preference and repurchase intention model: the role of consumer experience. Journal of Marketing Management, 32(13-14), 12301259. https://doi.org/10.1080/0267257X.2016.1150322

Foster, C., \& Resnick, S. (2013). Service worker appearance and the retail service encounter: the influence of gender and age. The Service Industries Journal, 33(2), 236-247.

https://doi.org/10.1080/02642069.2011.614341

Hooper, D., Coughlan, J., \& Mullen, M. (2008). Structural equation modelling: guidelines for determining model fit. Electronic Journal of Business Research Methods, 6(1), 53-60.

Hosany, S., \& Witham, M. (2010). Dimensions of cruisers' experiences, satisfaction, and intention to recommend. Journal of Travel Research, 49(3), 351-364.

https://doi.org/10.1177/0047287509346859

Iglesias, O., Markovic, S., \& Rialp, J. (2019). How does sensory brand experience influence brand equity? Considering the roles of customer satisfaction, customer affective commitment, and employee empathy. Journal of Business Research, 96, 343-354. https://doi.org/10.1016/j.jbusres.2018.05.043

Iglesias, O., Singh, J. J., \& Batista-Foguet, J. M. (2011). The role of brand experience and affective commitment in determining brand loyalty. Journal of Brand Management, 18(8), 570-582. https://doi.org/10.1057/bm.2010.58

Jeong, E., \& Jang, S. S. (2011). Restaurant experiences triggering positive electronic word-of-mouth (eWOM) motivations. International Journal of Hospitality Management, 30(2), 356-366. https://doi.org/10.1016/j.ijhm.2010.08.005
Karjaluoto, H., Munnukka, J., \& Kiuru, K. (2016). Brand love and positive word of mouth: the moderating effects of experience and price. Journal of Product \& Brand Management, 25(6), 527537. https://doi.org/10.1108/JPBM-03-2015-0834

Kim, J. H., Ritchie, J. B., \& McCormick, B. (2012). Development of a scale to measure memorable tourism experiences. Journal of Travel Research, 51(1), 12-25.

https://doi.org/10.1177/0047287510385467

Kim, J. W., Lee, F., \& Suh, Y. G. (2015). Satisfaction and loyalty from shopping mall experience and brand personality. Services Marketing Quarterly, 36(1), 62-76. https://doi.org/10.1080/15332969.2015.976523

Klein, J. F., Falk, T., Esch, F. R., \& Gloukhovtsev, A. (2016). Linking pop-up brand stores to brand experience and word of mouth: The case of luxury retail. Journal of Business Research, 69(12), 5761-5767. https://doi.org/10.1016/j.jbusres.2016.04.172

Koetz, C. (2019). Managing the customer experience: a beauty retailer deploys all tactics. Journal of Business Strategy, 40(1), 10-17. https://doi.org/10.1108/JBS-09-2017-0139

Kylkilahti, E., \& Autio, M. (2018). Young and recognized in service interaction? Re-positioning youth and adulthood with performance tactics and strategicmlaughter. Young, 26(1), 17-33. https://doi.org/10.1177/1103308816678742

Liu, Y., \& Jang, S. S. (2009). Perceptions of Chinese restaurants in the US: what affects customer satisfaction and behavioral intentions? International Journal of Hospitality Management, 28(3), 338-348. https://doi.org/10.1016/j.ijhm.2008.10.008

Mohammed, G. O., Hasaballah, A. H. A., Almohaimmeed, B. M. A., \& Al-Tit, A. (2017). The impact of product performance on brand loyalty mediated by customer satisfaction: Study in Sudanese service industry. International Journal of Advanced and Applied Sciences, 4(1), 116-122. https://doi.org/10.21833/ijaas.2017.01.017

Nysveen, H., Pedersen, P. E., \& Skard, S. (2013). Brand experiences in service organizations: Exploring the individual effects of brand experience dimensions. Journal of Brand Management, 20(5), 404-423. https://doi.org/10.1057/bm.2012.31

Parahoo, S., Harvey, H., \& Radi, G. (2014). Changing consumer behavior paradigms: does passenger age impact factors influencing MRT usage? Corporate Reputation Review, 17(1), 64-77. https:// doi.org/10.1057/crr.2013.25

Prentice, C., Wang, X., \& Loureiro, S. M. C. (2019). The influence of brand experience and service quality on customer engagement. Journal of Retailing and Consumer Services, 50, 50-59. https://doi.org/10.1016/j.jretconser.2019.04.020

Putra, A. N., Wulan, S., \& Ingkadijaya, R. (2018). The Influence of visualization of food appearance and food quality towards customer satisfaction in Tutup Panci Bistro, Bumi Serpong Damai, South Tangerang. TRJ Tourism Research Journal, 2(2), 105-116. https://doi.org/10.30647/trj.v2i2.42

Rahman, S. M. (2012). Dynamics of consumers' perception, demographic characteristics and consumers' behavior towards selection of a restaurant: an exploratory study on Dhaka city consumers. Business Strategy Series, 13(2), 75-88. https://doi.org/10.1108/17515631211205488

Schmitt, B. (1999). Experiential marketing; how to get customers to sense, feel, think, act and relate to your company and brands. Free Press.

Shanti, M., Sunaryo, S., \& Rofiq, A. (2019). Cognitive affective aspects of forming brand loyalty. Jurnal Aplikasi Manajemen, 17(2), 275-284. https://doi.org/10.21776/ub.jam.2019.017.02.10

Shi, D., Lee, T., \& Maydeu-Olivares, A. (2019). Understanding the Model Size Effect on SEM Fit Indices. Educational and Psychological Measurement, 79(2), 310-334.

https://doi.org/10.1177/0013164418783530 
Sweis, R. J., Al-Mansour, A., Tarawneh, M., \& Al-Dweik, G. (2013). The impact of total quality management practices on employee empowerment in the healthcare sector in Saudi Arabia: a study of King Khalid Hospital. International Journal of Productivity and Quality Management, 12(3), 271-286.

https://doi.org/10.1504/IJPQM.2013.056149

Verhoef, P. C., Lemon, K. N., Parasuraman, A., Roggeveen, A., Tsiros, M., \& Schlesinger, L. A. (2009). Customer experience creation: Determinants, dynamics and management strategies. Journal of retailing, 85(1), 31-41.

https://doi.org/10.1016/j.jretai.2008.11.001

Wägar, K., \& Lindqvist, L. J. (2010). The role of the customer contact person's age in service encounters. Journal of Services Marketing, 24(7), 509-517. https://doi.org/10.1108/08876041011081069
Wu, C. H. J., \& Liang, R. D. (2009). Effect of experiential value on customer satisfaction with service encounters in luxuryhotel restaurants. International Journal of Hospitality Management, 28(4), 586-593. https://doi.org/10.1016/j.ijhm.2009.03.008

Zhang, X. (2019). Research on the influence factors of brand experience on consumers' brand loyalty. Open Journal of Business and Management, 7(2), 556-561.

https://doi.org/10.4236/ojbm.2019.72038

Zniva, R., \& Weitzl, W. (2016). It's not how old you are but how you are old: A review on aging and consumer behavior. Management Review Quarterly, 66(4), 267-297.

https://doi.org/10.1007/s11301-016-0121-z 